\title{
Linguistic Diffusion in the Development of Hausa Language
}

\author{
${ }^{1, *}$ Hamzat Na'uzo Abdulkadir
}

Department of English, University of Abuja, Abuja, , Nigeria

Received: 01.02.2020 • Accepted: 20.03.2021 • Published: 31.03.2021 • Final Version: 31.03.2021

\begin{abstract}
The purpose of this paper is to prove that intercultural relationship and sufficient contact between Hausa and other languages result in linguistic diffusion or borrowing. The study adopts both the historical and descriptive survey research design, predicated on the need for a brief history of Hausa and the donor languages, and descriptive design to facilitate the use of secondary data generated from textbooks, theses, dissertations, seminar and conference papers. The study traces the location of Hausa people in order to vividly comprehend the nature of contact with the donor languages which effectively bears on the objective nature of the borrowed words. It is in this light that three types of language relationship emerged: genetic, typological and cultural. The intercultural relationship can be unidirectional (English and Hausa) or bi-directional (Hausa and Yoruba). The work provides concrete examples from Tuareg, Fulfulde, Kanuri, Yoruba, Nupe, Arabic and English languages to demonstrate the long contact with the Hausa language. The study finally observes suppressive interference on the structures of Hausa especially from Arabic and English, which have attained second language status in Hausa society, which, again, does not make the language lose its originality.
\end{abstract}

Keywords: borrowing; linguistic diffusion; Hausa; language.

\section{Introduction}

BECAUSE OF THE CONFUSION SLAMMED ON borrowing, language engineering is today most favoured by linguists. What you borrow you return some day but borrowing between languages goes beyond temporary possession, as the loan words remain permanent in the recipient languages. Borrowing is natural for the expansion of lexicon through importation, adaptation, modification, translation, substitution, and creation of new words to enable the recipient language to cope with the exigencies of modern science and technology, philosophy, and ideology which are useful in "orthography design, corpus planning, material development, encouragement of Language use at all levels to account for

\footnotetext{
*Corresponding Author. hamza.abdulkadir@uniabuja.edu.ng
} 
and communicate the changing experiences of the speakers as well as all aspects of the human legacy called knowledge" (Capo 1990:2).

The nature of contact determines the objective character of the vocabulary items borrowed. The paper will illustrate the issues at hand by allusion to the consequences of such endeavour and the universal character of the concept of borrowing since the national language policy in the country has given priority to the development of the indigenous mother tongues. Hausa, a living and dynamic language, borrows from many languages. However, the discussion will be limited to seven most influential and significant languages: Tuareg, Fulfulde, Kanuri, Yoruba, Nupe, Arabic, and English.

\subsection{1 Concept of Language}

Linguists, from traditional grammarians, formalists (structuralist, generativists, transformationalists) functionalists, sociolinguists, to communicativists have given different definitions to language. Since language engineering is concerned with the adaptation of new lexical items from one language to another to express ideas, objects, emotions, concepts, places, and so on, to meet new challenges in ideological, scientific, and technological innovations, the most appropriate and socially convenient working definition to this paper is that provided by Sapir:

Language is a purely human and non-instinctive method of communicating ideas, emotions and desires by means of a system of voluntarily produced symbols (1921:8).

Language is therefore an organized 'noise' used in situations or as contextualized systematic sounds. Not only in English but also in other languages, language is an act of using meaningful noise and it therefore plays a vital role in human existence. It is as important as other basic requirements of life. As air, water, and food are essentials for natural survival so also we need language for psychic survival and for social relationship. This is the contention of Holmes (cited in Kuju 1997: 2) that 'language is the blood of the soul into which thoughts run and out of which they grow'. Since language is indispensable to human existence, it suffices to say that the process of borrowing between languages is natural.

\subsection{Location of Hausa People}

To mention the location of Hausa people is a necessary and sufficient condition in order to vividly comprehend the nature of contact with the donor languages. Hausaland is situated in West Africa, in the Northern part of Nigeria and the southern part of Niger Republic, specifically Maradi. To the East it forms a boundary with Borno, Yobe, and Adamawa States, and to the West with Benin Republic through River Niger. To the South it forms a common boundary with Gwariland, southern Kaduna and southern part of Bauchi State. Hausa towns include Kano, Daura, Katsina, Sakkwato, Zazzau, Kwantagora, and the Northern part of Bauchi State. In Niger Republic, such towns include Kwanni, Maradi, and Damagaram. Today, apart from Swahili, Hausa is probably the most widely spoken indigenous language in Africa south of the Sahara Desert. It is used as a first language by over 70 million people in its central area covering most of the northern part of Nigeria and 
southern Niger Republic. This is probably the reason for its recognition by the language bureau of OAU now the African Union (AU) as one of the two official languages in Africa. Salim (1981: 3) observes that 'Hausa enjoys a wide-spread usage, as a minority language and/or lingua franca, in most West African countries and within certain settler clusters in parts of Northern and Central Africa'.

\section{Language Relationship and Linguistic Engineering}

There are basically three types of language contact or relationships that lead to borrowing between languages. The First is genetic relationship where the languages share common historical origin. Examples are Hausa and Gwandara, or modern English and modern Saxon. The second is a typological relationship where the languages are identical especially in terms of syntactic behaviour. Examples are Igala and Yoruba. The third is cultural relationship, which is the most common especially between African languages and the major exoglossic or exonomatic languages in Africa, such as English, French, Portuguese, Spanish, Malayo-Polynesian, and Afrikaans (which has a Dutch origin). The third form of relationship is most relevant to our discussion because the existence of the loan words is the result of sufficient contact between the languages.

However, before a language comes into contact with another, it must have been sufficiently equipped to cater for its local needs. The contact will bring different cultures, ideas, norms, values and ideologies together. This intercultural relationship rationalizes the idea of linguistic engineering or borrowing. The borrowing might be unidirectional as it is between English and Hausa or bi-directional or mutual as between Hausa and Yoruba (Bamgbose 1991).

As expected, borrowing between languages does not include basic words no matter the degree of contact between the languages. Basic words refer to objects every language is familiar with, no matter where the geographical locations of the speakers may be. Words of natural phenomena such as the sky, earth, sun, moon, stars, water and some parts of human body such as hands, head, eyes, nose, mouth, and legs are not borrowed.

\section{Languages from which Hausa Borrows}

Tuareg, Fulfulde, Kanuri Yoruba, Nupe, Arabic, and English Languages have had long cultural contact with Hausa to the extent that the question of borrowing becomes inevitable.

\subsection{Tuareg}

The Tuareg came to Hausaland from Niger Republic and Mali for trade purposes since the establishment of the seven Hausa States. Later, famine forced them to settle in Kano during the reign of Bagauda. Their refusal to go back to their homes after famine led to inter-marriage between them and the Hausa people. Consequently, this led to the adoption of their words into the Hausa Language. The following words with etymology from the Tuareg reflect the trade nature of contact between the languages.

$\begin{array}{lll}\text { Tuareg } & \text { Hausa } & \text { Gloss } \\ \text { Ayaran } & \text { Ayari } & \text { Trade- caravan } \\ \text { Takoba } & \text { Takobi } & \text { Sword } \\ \text { Kanwa } & \text { Kanwa } & \text { Potash }\end{array}$




$\begin{array}{lll}\text { Takarde } & \text { Takarda } & \text { Paper } \\ \text { Ejak } & \text { Jaki } & \text { Donkey }\end{array}$

The Tuareg came with the trade-caravans and they brought along with them potash, paper, donkeys, and swords to Hausaland. The loan words may have been new to the Hausa, and so borrowing became necessary. We should note that most words in Hausa end with a vowel as Hausa syllables are without a coda (cf. Abdulkadir H. Na'uzo 2004). The loan words had to undergo certain phonological and orthographical transformations in order to suit the needs of the language as clearly demonstrated in the case of 'ayaran' changing to 'ayari'.

However, the existence of these loan words is not to deny the fact that Hausa has similar names for them. For instance, 'takobi' has another name in Hausa, namely 'Kansakali' meaning 'sword'.

\subsection{Fulfude}

The Fulani or Fulbe came to Hausaland from the Futa Jallon area, in the Senegal, during the reign of Emir Yakubu of Kano (1452- 1463). They specifically carne to trade and to propagate the Islamic religion. The most obvious contact was when Shehu Usmanu Danfodio led the Fulani in the Islamic Jihad (war) from 1804-14 into all parts of Hausaland. The Fulani, like the Normans who conquered England and failed to impose their language on the English because of their numerical weakness, found themselves speaking Hausa language. This could be the linguistic reason for the emergence of a class in northern Nigeria called the Hausa-Fulani, which serves a cover term for those Fulani who lost their language but are still nostalgic about it. However, the inter-language contact was so much as to allow for borrowing. The following loan words reflect their trade, and the feudal and kinship nature of the relationship between the two languages. Because most of these words and their concepts are foreign to Hausa, it became necessary to adopt them.

$\begin{array}{lll}\text { Fulfulde } & \text { Hausa } & \text { Gloss } \\ \text { Allah Seine } & \text { Alasaini } & \text { May God give you happiness } \\ \text { Allah Reine } & \text { Alaraini } & \text { May God bless you } \\ \text { Kindirimu } & \text { Kindirmo } & \text { Youghurt } \\ \text { Bukkaro } & \text { Bukka } & \text { Hut } \\ \text { Bappa } & \text { Baffa } & \text { Paternal Uncle } \\ \text { Kawu } & \text { Kawu } & \text { Maternal Uncle } \\ \text { Goggo } & \text { Gwaggo } & \text { Aunt } \\ \text { Nadittijo } & \text { Dattijo } & \text { Gentleman }\end{array}$

\subsection{Kanuri}

The inter-language contact between Hausa and Kanuri was equally substantial enough to allow for language engineering. The nature of contact was also not unconnected with trade, 
Another strong reason was the conquest of some western parts of Hausaland by Mai Idris Katagarambe of Borno in 1526. The conquest reverberated throughout Hausaland, including Kano, Katsina, Gobir and Kebbi. Loan words which reflect the objective character of the contact include the following:

$\begin{array}{lll}\text { Kanuri } & \text { Hausa } & \text { Gloss } \\ \text { Turbo } & \text { Turba } & \text { Path/Road } \\ \text { Tumbul } & \text { Tambari } & \text { Royal Drum } \\ \text { Burabusko } & \text { Burabisko } & \text { Millet Food } \\ \text { Ciroma } & \text { Ciroma } & \text { Traditional Title } \\ \text { Yarima } & \text { Yarima } & \text { Prince }\end{array}$

\subsection{Yoruba}

The Yoruba people are found mostly in Kwara, Oyo, Ondo, Ogun, Osun, Ekiti, and Lagos States, and southeastern part of Benin Republic. Hausa traders used to export cattle and rams to Yorubaland in exchange for kolanuts, matches, clocks, and clothes (a trade that is still going on). The 1804 jihad of Usmanu Danfodio brought Ilorin and some Yoruba towns under the influence of a Hausa-Fulani culture. Below are some of the most popular loan words:

$\begin{array}{lll}\text { Yoruba } & \text { Hausa } & \text { Gloss } \\ \text { Apoti } & \text { Akwati } & \text { Box } \\ \text { Isana } & \text { Ashana } & \text { Matches } \\ \text { Pata Pata } & \text { Kwata Kwata } & \text { Completely } \\ \text { Owoloja } & \text { Awalaja } & \text { Cash down with the implication } \\ & & \text { 'take it or leave it' } \\ \text { Kpaki } & \text { Kwaki } & \text { Cassava } \\ \text { Kpano Kpano } & \text { Kwana Kwana } & \text { Fire Brigade }\end{array}$

\subsection{Nupe}

Nupe is another Nigerian language that had sufficient contact with Hausa to permit borrowing. Nupe people are predominantly living in Niger State and the northern part of Kwara State. Traditionally, Nupe people are unparalleled in sewing and smithing industries. They brought their dresses also to Hausa people to buy. Danfodio's Jihad intensified the contact between the languages.

$\begin{array}{lll}\text { Nupe } & \text { Hausa } & \text { Gloss } \\ \text { Gulu } & \text { Angulu } & \text { Vulture } \\ \text { Gbamba } & \text { Agwagwa } & \text { Duck }\end{array}$



Kpalaba
Kwalaba
Bottle

\subsection{Arabic}

Of all the languages Hausa borrows from, Arabic is unequalled. Historians have shown that the Arabs started coming to Hausaland in about 1194-1247 during the reign of the emir of Kano Magaji Dari Bariku. They came for trade purposes and later to propagate the religion of Islam. The Hausas accepted this new religion and the Arabic alphabet. Because of the religion's powerful influence on the Hausa people, most Hausa customs, festivals, laws, mores, and folkways came to mix with those of the Arabs. In almost all walks of life in Hausa society we encounter cultural practices shared by the two languages.

\section{Religion}

Arabic

Allahu

Al-Nabiyu

Al-Qur'an

Hadith

Zakkat

Swalat

Al-Siyam

Hajj
Hausa

Allah

Annabi

Kur'ani

Hadisi

Zakka

Salla

Azumi

Hajj
Gloss

God

Prophet

Quran

Prophet's tradition

Compulsory Alms

Prayer

Fasting

Pilgrimage

\section{Administration}

$\begin{array}{lll}\text { Arabic } & \text { Hausa } & \text { Gloss } \\ \text { Hukumatun } & \text { Hukuma } & \text { Government } \\ \text { Hakimun } & \text { Hakimi } & \text { District Head } \\ \text { Muulkun } & \text { Mulki } & \text { Administration } \\ \text { Kharaji } & \text { Haraji } & \text { Poll Tax } \\ \text { Jumhuriya } & \text { Jamhuriya } & \text { Republic } \\ \text { Siyasat } & \text { Siyasa } & \text { Politics } \\ \text { Baitulmal } & \text { Baitulmali } & \text { Treasury }\end{array}$

\section{Law}

Arabic

Hausa

Gloss

Al-qadi

Alkali

Judge

Shahidun

Shaida

Witness 


$\begin{array}{lll}\text { Iqrawun } & \text { Ikrari } & \text { Confession } \\ \text { Qadhaf } & \text { Kazafi } & \text { False Accusation }\end{array}$

\section{Education}

Arabic

Al-ilmu

Mu-allimun
Hausa Gloss

Ilimi Knowledge

Malami Teacher

\section{Food stuff}

Arabic

Al-qama

Al-basl

Kurasun

\section{Dress}

Arabic

Qaftam

Taqiyya

Hurmalatun
Hausa

Alkama

Albasa

Gurasa

Hausa

Kaftani

Tagiya

Falmaran

\section{Gloss}

Wheat

Onion

Wheat baked food

\section{Counting}

Arabic

Hausa

Gloss

Ishrun

Ashirin

Twenty

Miatun Thalathun

Metan

Two Hundred

Talatin

Thirty

\section{Culture}

Arabic

Janaza

Dallatun

Sabunun

Qazaratun
Hausa

Jana'iza

Dillali

Sabulu

Kazanta

\section{Gloss}

Funeral

Middle-seller

Soap

Dirt

Arabic had so much contact with Hausa to the extent that many Hausa proverbs are influenced by the relationship. Hausa names such as Sale, Audu, Aminu and Ibro have their root in Arabic. 


\subsection{English}

Before the 1914 amalgamation of the Northern and Southern protectorates, there had been a series of contacts between the English and the Hausa people, most through the writings of British explorers and travelers. The English later colonized Hausaland and changed the administrative system through the so-called Indirect Rule system. The English introduced new ideas, values, culture, science, and technology which are mostly alien to the Hausa cultural practice. It will be practically impossible to assemble all known loan words from English to Hausa in this paper, though a fair representative sample of such loan words are as follows.

\section{Administration}

$\begin{array}{lc}\text { Hausa } & \text { English } \\ \text { Razdan } & \text { Resident } \\ \text { Sakatare } & \text { Secretary Governor } \\ \text { Gwamna } & \text { Commissioner } \\ \text { Kwamishina } & \text { Minister } \\ \text { Minista } & \end{array}$

The aforementioned posts and their concepts did not exist in Hausa society prior to the coming of the English so it became necessary to borrow in order to meet up with situation.

$\begin{array}{ll}\text { Law } & \\ \text { Hausa } & \text { English } \\ \text { Joji } & \text { Judge } \\ \text { Lauya } & \text { Lawyer } \\ \text { Kotu } & \text { Court }\end{array}$

\section{Security}

Hausa

English

Farabiti

Private

Samanja

Sergeat-Major

Bariki

Baracks

Caji Ofis

Charge Office

Fasa Ofis

Post Office

\section{Education}


90 Hamzat Na'uzo Abdulkadir

$\begin{array}{ll}\text { Hausa } & \text { English } \\ \text { Tebur } & \text { Table } \\ \text { Fensir } & \text { Pencil } \\ \text { Firamare } & \text { Primary } \\ \text { Kwaleji } & \text { College } \\ \text { Digiri } & \text { Degree }\end{array}$

\section{Science and Technology}

Hausa

Janareta

Safiyo

Gilashi

Waya

Fanka

Fyanti

Makanike

Trade

Hausa

Manaja

Banki

Farashi

Kanti

Dila

Sikeli

Food

Hausa

Far fesu

Burodi

Karas
English

Generator

Surveyor

Glass

Wire

Fan

Paint

Mechanic

English

Manager

Bank

Price

Canteen

Dealer

Scale

English

Pepper Soup

Bread

Carrot

\section{Dress}




$\begin{array}{ll}\text { Hausa } & \text { English } \\ \text { Kwat } & \text { Coat } \\ \text { Suwaita } & \text { Sweater } \\ \text { Turoza } & \text { Trousers }\end{array}$

The existence of certain lexical items in Hausa and the preference to borrow words that can be used to express the same concept occasioned the possibility of suppressive interference on the structures of the recipient language. This is distinct from the normal performance interference possibilities, which are universal and observable whenever any pair of human languages comes into contact. Suppressive interference is observed in Hausa because both Arabic and English have reached second language status in Hausa society.

Performance interference is reflected in the Arabic or English of Hausa speakers either as Arabic-as-a-Second-Language (ASL) or as English-as-a-Second-Language (ESL) learners respectively; just as it is found in the Hausa spoken by native Arabic and English speakers. Lexical borrowing takes place in all cases of language contact. It becomes suppressive when the borrowed item so displaced an existing native word for the same concept or object that some native speakers of the recipient language are unaware of the existence of the native word.

For instance, 'kansakali' is a Hausa word for sword which has been replaced by 'takobi', a loanword from Tamashek, the language of the Tuareg. Similarly, 'Gidan Yari' exists as 'prison' which has been replaced by 'gidan fursuna', a loanword from English. 'kankana', meaning 'water melon', exists in Hausa which has also been replaced by 'wata mela. Other words are 'langabu', 'ganda', and 'Qauri', that have been replaced by 'parpesu', a loanword from English meaning 'pepper soup'.

However, suppressive interference or even abundance of so many loan words in a language will not make the recipient language to lose its originality or 'ancestral texture' (whatever that means) as feared in some quarters. Borrowing is natural and any language that refuses to borrow may die or face devolution as in the case of Latin in' the $3^{\text {rd }}$ and $4^{\text {th }}$ century A. D., which gave birth to Romance languages such as French, Italian, Haitian, Portuguese, Spanish, etc.

Given the ideological, scientific, and technological advancement in the world today, no language can afford to lag behind despite all the nationalistic cries and lamentations about foreign words. The dynamics of language change are real because they reflect the sociolinguistic and psycholinguistic realities of languages. Languages must therefore be encouraged to borrow from other languages.

Moreover, the existence of equivalent lexical items to the loan words in Hausa demonstrates the dynamics and development of the language; and, as a living language, it is fashionable for it to borrow in order to change with the needs of the coming language, taking into cognizance the needs of its own native speakers. Other loan words cited and their concepts did not exist in Hausa prior to the contact situation which made their adoption a necessity. 
Furthermore, the case of Hausa borrowing from less prestigious languages to enrich itself has debunked the traditional fallacy that only less prestigious languages borrow from more prestigious ones. It can be observed, prejudice aside, that of all the donor languages to Hausa cited in this paper with the exception of English and Arabic, none is more prestigious and none enjoys wider usage than Hausa (cf. Bamgbose 1991; Bamgbose et al.1995)

Although linguists have not been able to establish the existence of Hausa loan words in English and Arabic, one can still see instances of borrowing, in the case of English, from other languages. Bough and Cable (1983: 264) observe that not only had English borrowed much in the past, but, as they frequently point out, all other languages, including Latin and Greek had enriched themselves in this way.

Since borrowing can increase the linguistic richness of a language, little wonder then that George Pettie, the translator of Guozzo's Civile Conversations, finds it a fault in himself in refusing to use borrowed terms, for it is, according to him, ... the ready way to enrich our tongue and make it copious, and it is the way which all tongues have taken to enrich themselves (cited in Bough and Cable, 1983:265). Bullocar caps it all when he says that 'it is familiar among best writers to usurp strange words' (cited in Bough and Cable 1983: 265).

\section{Conclusion}

When there is a sufficient contact between languages, the possibility of one influencing the other or both influencing each other cannot be ruled out. This is a genuine justification for the experience of loan words in Hausa which obviously reflects the nature of contact between the donor languages and Hausa. Hence, many of the loan words and their concepts did not exist in Hausa society until such contacts were made possible. Since Hausa is a living language, the borrowing naturally stimulates the linguistic change and development we have observed in the language.

\section{Acknowledgment}

Acknowledgment and/or disclaimers should appear before References. Names of funding organizations should be written in full. The authors are advised to describe author contributions, e.g., as follows: S.A. gave the idea, F.A. did the experiments, F.A. and S.A. interpreted the results, S.A. wrote the paper.

\section{References}

[1] Abdulkadir, H. N. (2007). "Language and Ideology: A sociolinguistic Appraisal" in FAIS Journal of Humanities Vol. 3 No. 6. Pp. 169-190.

[2] Abdulkadir, H. N. (2004). "Divergence in Syllable Structures; The Problems Encountered by Hausa Speakers of English in Internalizing the Syllable Structure Rules of English" in Kakaki: A Journal of English and French Studies Bayero University Kano. Vol. 1 No. 1 Pp. 135-147. December 2004 
[3] Amfani, A. H. (2008). "Globalization and the Documentatin of Nigerian Laanguages". The Nigerian Linguistic Festschrift Series. Vol. 7. Pp. 97-144.

[4] Auta, L. A. (1985). "Tarihin Asalin Hausawa Daga Bakin Mawakan Fada Da Na Jarna'a". Unpublished Seminar Paper Presentation, Faculty of Arts and Islamic Studies, Bayero University, Kano, $13^{\text {th }}$ March, 1985.

[5] Balarabe, A. B. (2013). Karin Magana a Cikin Littattafan Adabin Kasuwar Kano na Mata. Unpublished M.A. Thesis, Usumanu Danfodiyo, University, Sokoto.

[6] Bamgbose, A. (1991). Language and the Nation: The Language Question in Suh-Saharan Africa, Edinburgh: Edinburgh University Press.

[7] Bamgbose, A. et. al (eds) (1995). New Englishes: A West African Perspective, Ibadan: Musuro Publishers.

[8] Bature, A. (1985). "Gudummuwar Sauran Harsuna Wajen Habaka Harshen Hausa". Unpublished paper presented at the Hausa Week, Bayero University, Kano, 17th April 1995

[9] Bough, A. C. and Cable, T. (1983). A History of the English Language. London: Routledge and Kegan.

[10] Capo, H. B. C. (1990). "Comparative Linguistics and Language Engineering in Africa" in E. N. Emenanjo, Multilingualism, Minority Languages and Language Policy in Nigeria, Port Harcourt: Central Books Ltd. Pp. 1-9.

[11] Chomsky, N. (1986). Knowledge of language. Its nature origin and use. New York: Praeger Publishers.

[12] Emenanjo, E. N. (1993). "Lessons in Language Development for the Small Nigerian Languages from the Major Nigerian Languages" in R. Aziza and N. Emenanjo (eds) Teaching Nigerian Languages: Experience from the Delta, Warri: COEWA Publishers.

[13] Emen, C. O. (1996). "Borrowing in Igbo Language: Sociolinguistic Survey", Ikere: Journal of Languages. Vol. 1(1). Pp. 36-56.

[14] Kuju, M. (1995). "Language Holocausts". The Meridian. No. 16. Pp. 24-28.

[15] Maishanu, H. H. (2007). Five Centuries of Historical Writings in Hausa Language and Borno, 1500-2000. Nigeria: Macmillan.

[16] Ronald, W. C. (1923). Language and Its Structure, New York: University of California Press.

[17] Oyetade, S. O. (2010). The English Language in Nigeria (Eds). National Open University of Nigeria.

[18] Salim, A. B. (1981). "Linguistic Borrowing as External Evidence in Phonology: The Assimilation of English Loan words in Hausa". Unpublished PhD Thesis, University of York.

[19] Sapir, E. (1921). Language: An Introduction to the Study of Speech. New York: Harcourt Brace.

[20] Ugwuoke, M. J. (1997). "Linguistic Diffusion: The Igbo Language Experience". Unpublished paper presented at the 15th LAN Conference held at the Usumanu Danfodio University, Sokoto, 3rd- 7th November, 1997

[21] Weinreich, U. (1968) Languages in contact findings and problems. The Hague Mouton

[22] William, K. (1988). The Pedegree of Nations Historical Linguistics. Port Harcourt. University of Port Harcourt Press. 